\title{
SHALLOW OR DEEP? A REINTERPRETATION OF THE RIFIAN CORRIDOR'S UNIQUE SANDY CONTOURITES
}

\author{
DAAN BEELEN ${ }^{1}$, LESLI J. WOOD ${ }^{1}$, MOHAMED NAJIB ZAGHLOUL ${ }^{2}$, MICHIEL \\ ARTS $^{3}$, and J. FREDRICK SARG ${ }^{1}$

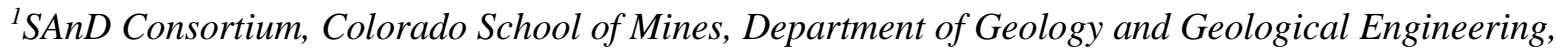 \\ 1500 Illinois Street, Golden, Colorado, United States of America.dbeelen@mines.edu, \\ lwood@mines.edu, jsarg@mines.edu \\ ${ }^{2}$ Université Abdelmalek Essâ̂di, Faculté des Sciences et Techniques, PO Box 416, Tanger, 90000, \\ Morocco,zaghloul@geologist.com \\ ${ }^{3}$ Université de Liège, Faculté des Sciences, Département de Géologie Sedimentary Petrology, Allée \\ du Six Août, 12, B20, 4000 Liège, Belgium,michiel.arts@uliege.be \\ Twitter: @daanosaurus_rex
}

This manuscript is a preprint published on February 24, 2021 in the preprint server EarthArXiv. It has also been submitted for publication in the peer-reviewed journal: Sedimentology. Although the contents of this preprint are true and complete according to the authors, future versions may have slightly different wording or figures. Please contact the lead author Daan Beelen (dbeelen@mines.edu) if you have any questions or comments about this preprinted manuscript. Earth ArXiv 


\section{ABSTRACT}

This study proposes that sandstone layers exposed in the Fez-Meknes region of Northern Morocco (Ben Allou (Sidi Chaded) and El Adergha localities), have been misinterpreted as unique examples of geostrophically-driven, deep marine (150 - $400 \mathrm{~m}$ water depth) sandy contourites. Instead, our independent paleontological, sedimentological, and stratigraphic analyses show that these sandstones represent more common, shallow marine ( 0 - $30 \mathrm{~m}$ water depth) tide-dominated deltas. Our findings imply that at least seven existing studies have based their interpretations on erroneous paleo water depth reconstructions. These have been derived from foraminiferal assemblages from siltstone and claystone layers that interbed the sandstones. Our foraminiferal data were obtained directly from all facies. These more complete data show that, while the siltstone and claystone layers can be considered deep marine, the sandstones are shallow marine, and previous studies did not account for major sea level fluctuations that occurred here during the late Miocene. Our reinterpretation has a defining impact on a wide scope of topics that have been covered by the existing body of work, which involves: the origin of global paleoclimate changes, sandy contourite facies models, conditions of bottom current controlled ecosystems and habitats, ichnofacies interpretations, changes in paleogeography, tectonics and reorganizations of global ocean currents and Mediterranean Outflow Water, and finally, geographic changes leading up to the disappearance of the Rifian Corridor and the associated Messinian salinity crisis. Using biostratigraphy and measurements of stratal thickness, we also establish that the successions here were responding to \pm 70 - $80 \mathrm{~m}$ amplitude, $100 \mathrm{kyr}$ period glacioeustatic fluctuations. These values represent hitherto unprecedented constraints on the nature of late Miocene climate fluctuations that were similar in period and intensity as Pleistocene glacial/interglacial cycles. Finally, we show that abundant authigenic sediment generation at the shallow marine fringes of the Rifian Corridor exacerbated its closure. This likely has significant, previously unrecognized implications to the onset of Mediterranean isolation and the associated Messinian salinity crisis. 


\section{INTRODUCTION}

Contourites are deep marine sedimentary deposits that have been 'emplaced or significantly affected' by geostrophic bottom currents (Rebesco et al., 2014). Despite being widespread in present day deep marine environments, ancient contourites in outcrop are rare. Reviews by Stow et al. (1998) and Hüneke and Stow (2008) list only seven outcropping deposits as 'possibly' or 'likely' representing ancient contourites. Because of their rarity, contourites in outcrop are much understudied (Rebesco et al., 2014). This lack of study is unfortunate, since these types of sedimentary deposits are relevant to a wide range of topics, as they: record paleoclimatic changes (Llave et al., 2006), changes in deep marine geostrophic currents (Hüneke and Stow, 2008; Knutz, 2008), provide insights into marine sedimentary processes (Shanmugam et al., 1993) and marine paleoecology (Miguez-Salas et al., 2020; Miguez-Salas et al., 2021), and finally, contourites are also associated with the exploration and extraction of deep marine earth resources (Viana et al., 2007; Viana and Rebesco, 2007).

In the field of ancient contourites, rocks occurring in one specific interval: the upper Tortonian (upper Miocene) of the Rifian Corridor, are of unique interest. These rocks exhibit a coarse grainsize, suggesting deposition under powerful current conditions, and are comprised of relatively young, unaltered sedimentary rocks with well-established biostratigraphic age constraints, allowing accurate sedimentary and stratigraphic analysis (Capella et al., 2017). The Rifian Corridor; an ancient sea strait that existed between the Mediterranean Sea and the Atlantic Ocean, also played a key role in the development of Mediterranean Outflow Water (MOW) and the onset of the Messinian salinity crisis (Ivanovic et al. 2013). Deposits of Rifian Corridor fill are best exposed at the localities of Ben Allou (also called Sidi Chahed) and El Adergha, which are both within $30 \mathrm{~km}$ of the city of Fez (Fez-Meknes Region, northern Morocco, $34^{\circ} 02^{\prime} \mathrm{N} ; 5^{\circ} 0^{\prime} \mathrm{W}$; Fig. 1). There is a growing body of research on these outcrops, which interpret these rocks as unique and critically important outcrop analogues to deep marine sandstone contourites (Capella et al., 2017). Based on this interpretation, these authors press forward with their insights into the late Miocene palaeoenvironment and paleoceanography. Based on their interpretations, authors have variously: 1) inferred global paleoclimate changes (Capella et al., 2019), 2) developed facies models for bottom current-controlled sedimentary environments (Stow and Smilie, 2020), 3) inferred reorganizations of global ocean currents (Capella et al., 2019; de Weger et al., 2020), 4) reconstructed conditions of bottom current-controlled ecosystems and habitats (MiguezSalas et al., 2020a; Miguez-Salas et al., 2020b; Miguez-Salas et al., 2021), 5) inferred changes in paleogeography (Capella et al., 2017; Miguez-Salas et al., 2020b) and tectonics (Capella et al., 2017; Stow and Smilie, 2020; de Weger et al., 2020) and 6) redefined ichnofacies interpretations (MiguezSalas et al., 2021), 7) and reconstructed bottom current and MOW changes near the onset of the Messinian salinity crisis (Capella et al., 2017; Capella et al., 2019). 


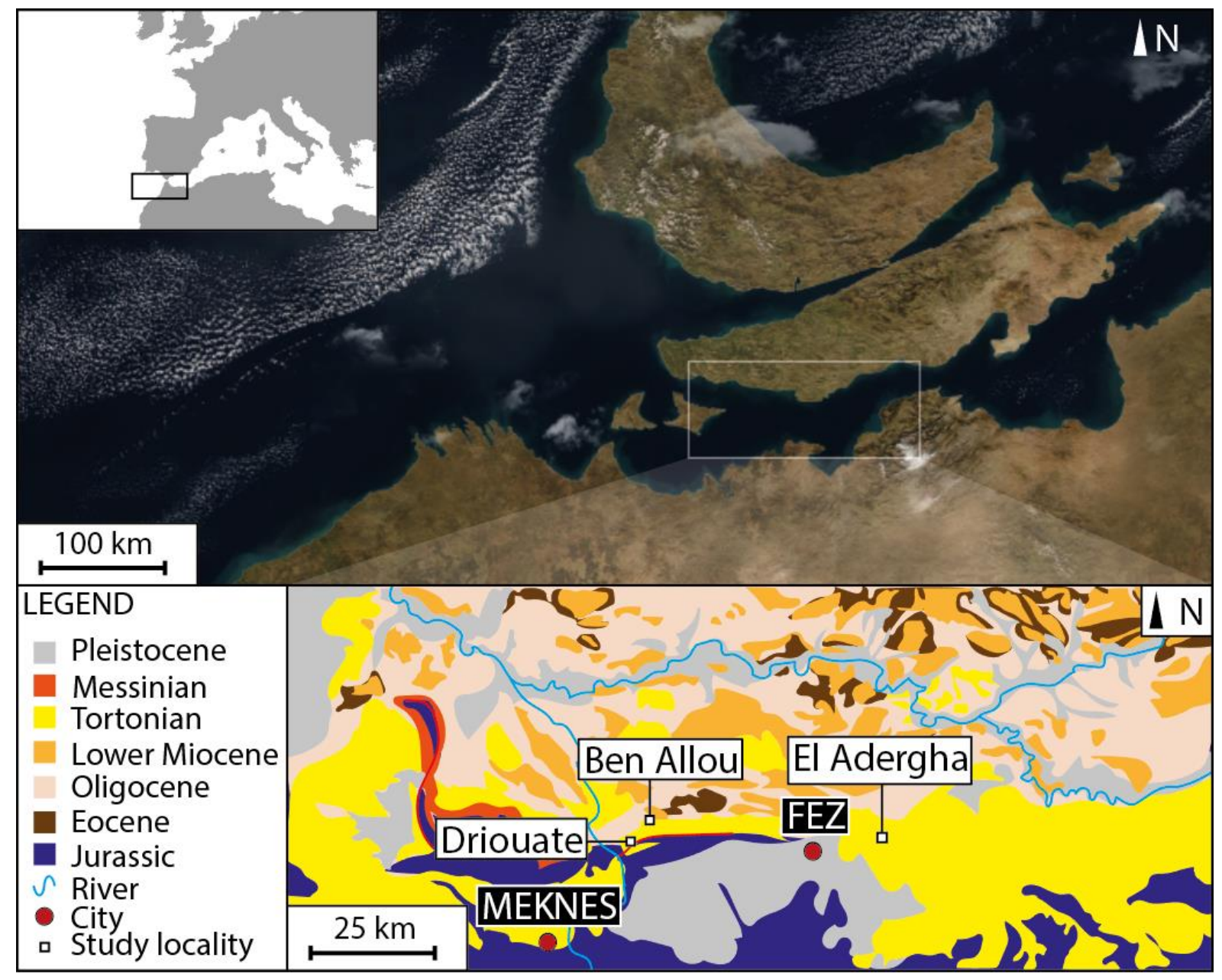

Figure 1. Top left: location of paleogeographic reconstruction (black box) is shown relative to the European Continent. Top: Paleogeographic reconstruction showing the northern and southern Rifian Corridors. White box shows the location of geological map at the bottom of the image. Bottom: Geological map of the field area with two localities (Ben Allou and El Adergha) shown relative to the cities of Fez and Meknes.

The deep marine palaeoenvironmental setting for these outcrops was first argued for in Zizi (1996) and then further evaluated in Capella et al. (2017). The latter study estimated a depositional water depth of 150 - $400 \mathrm{~m}$, based on microfossil assemblages from siltstone and claystone facies that alternate with sandstone intervals at the locations of Ben Allou and El Adergha (Capella et al., 2017; Stow and Smillie, 2020). Paleo water depth reconstructions for these sandstones were then assumed to be the same as those interpreted for the surrounding siltstones and claystones (Capella et al., 2017). Several subsequent studies rely upon these interpreted depositional water depths for their environmental and process interpretations (Capella et al., 2017; Capella et al., 2019; de Weger et al., 2020; Miguez-Salas et al., 2020a; Miguez-Salas et al., 2020b; Miguez-Salas et al., 2021; Stow and Smilie, 2020). In this study, we present new data from the same outcrops examined by the previously mentioned authors, including independent microfossil assemblages from the siltstone, claystone and sandstone facies. These data lead 
us to conclude that the sandstones were deposited in shallow water, while the siltstones and claystones developed in much deeper water. This conclusion has defining implications for all the previously cited work on deep water sandy contourites in this area. In addition to our analysis of foraminiferal assemblages, we present independent macrofossil, ichnological, and sedimentary analysis, to verify and corroborate our findings, and develop independent interpretations on the depositional history of these key deposits.

\section{Regional context}

The northward movement of the African plate induced the formation of an orogenic arc that surrounded the western Mediterranean Sea, circa 20 Ma. The southern portion of this arc trends throughout northern Morocco, where it is called the Rif Orogenic Arc. This arc is comprised of a mountain range and foreland basin called the Rif foreland basin, which is further separated into smaller basins, with each smaller basin bounded by thick-skinned normal faults (Zizi, 1996). The sediments considered in this study formed in one such sub basin called the Saïss Sub basin (Beelen et al., 2020).

Outcrop localities that expose these sediments are labelled according to historical names provided in the literature (Figs. 1,2). The primary outcrops of study in this research are called Ben Allou (34 $5^{\prime} 52.78^{\prime \prime}$, $5^{\circ} 18^{\prime} 32.43^{\prime \prime W}$ ). Some studies use the name Sidi Chahed in reference to these outcrops (e.g. de Weger et a., 2020). This outcrop exposes 209 meters of stratigraphy. In addition to this outcrop, there is a much smaller outcrop called El Adergha, which contains 25 meters of exposure located $40 \mathrm{~km}$ east of Ben Allou. Both outcrops contain contemporaneous sandstone intervals that have been interpreted as deep marine sandstone contourites (e.g. Capella et al., 2017).

\section{METHODS}

Observations were made in the field, in the Fez-Meknes Region of northern Morocco (Fig. 1). Foraminiferal assemblages were obtained from samples taken $10-15 \mathrm{~cm}$ depth within the exposed rocks. Several samples were taken from every facies across multiple intervals. Samples were washed and sieved using a 150 - micrometer sieve. More than 200 foraminiferal microfossils for every facies were isolated and then identified under a microscope. Microfossil facies assemblages are consistent

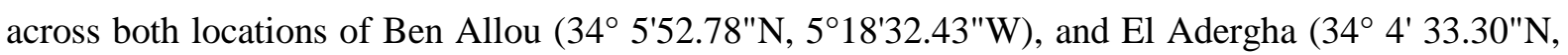
$4^{\circ} 51^{\prime} 36.56 \mathrm{WW}$ ), and across various intervals within the exposures. Although all facies have been interpreted as deep marine contourites by previous authors (see above), the sandstones (facies 3 ) are the primary subject of this study as these have received by far the least amount of scrutiny of their fauna, but are leaned on most heavily to support previous interpretations. 


\section{RESULTS}

The outcrops at Ben Allou expose a laterally continuous, up to 209-meter-thick succession of sedimentary rocks that formed between 7.80 and $7.50 \mathrm{Ma}$ (Capella et al., 2017). The succession here consists of three, approximately equally thick sedimentary cycles (Fig. 2, Beelen, et al., 2020). Each cycle comprises a basal facies 1: Blue claystones (mostly clay-sized sediments comprised of $\pm 23 \%$ $\mathrm{CaCO} 3$ ), overlain by facies 2: Grey siltstones (mostly silt-sized sediments comprised of $\pm 41 \% \mathrm{CaCO}_{3}$ ) interbedded with planar laminated sandstones, and capped at the top with facies 3: Yellow-brown sandstones. Facies 3: Yellow-brown sandstones always overlies laterally extensive surfaces of erosion (Fig. 3A). These sandstones, called thus due to their grain size, can also be called packestones (sensu Dunham, 1962) or calcarenites (sensu Grabau, 1904) because of their high fossiliferous nature and mass-percentage of $\mathrm{CaCO}_{3}( \pm 60 \%$, Beelen et al., 2020). The exposed sandstones show pervasive reactivation surfaces (Fig. 3B), inclined heterolithic stratifications (Fig. 3C), bidirectional cross-strata (Fig. 3D) and layers of small, muddy rip-up clasts, which sometimes form flaser bedding and mud drapes, occasionally containing mudcracks (Fig. 3E). Some intervals have symmetrical ripples (Fig. $3 \mathrm{~F}),>2 \mathrm{~m}$ tall tepee structures and well-cemented red hardgrounds where carbonaceous microfossils have been replaced by ferruginous minerals (Fig. 3G). Paleo-current direction indicators show a generally bidirectional flow, with a dominant uni-directional component (Capella et al., 2017). Large, $15 \mathrm{~m}-120 \mathrm{~m}$ wide channels are present throughout the sandstones. Exposures of channel fill are rhythmically bedded and show rapidly alternating layers of coarse- and fine-grained sandstones (Beelen et al., 2020).

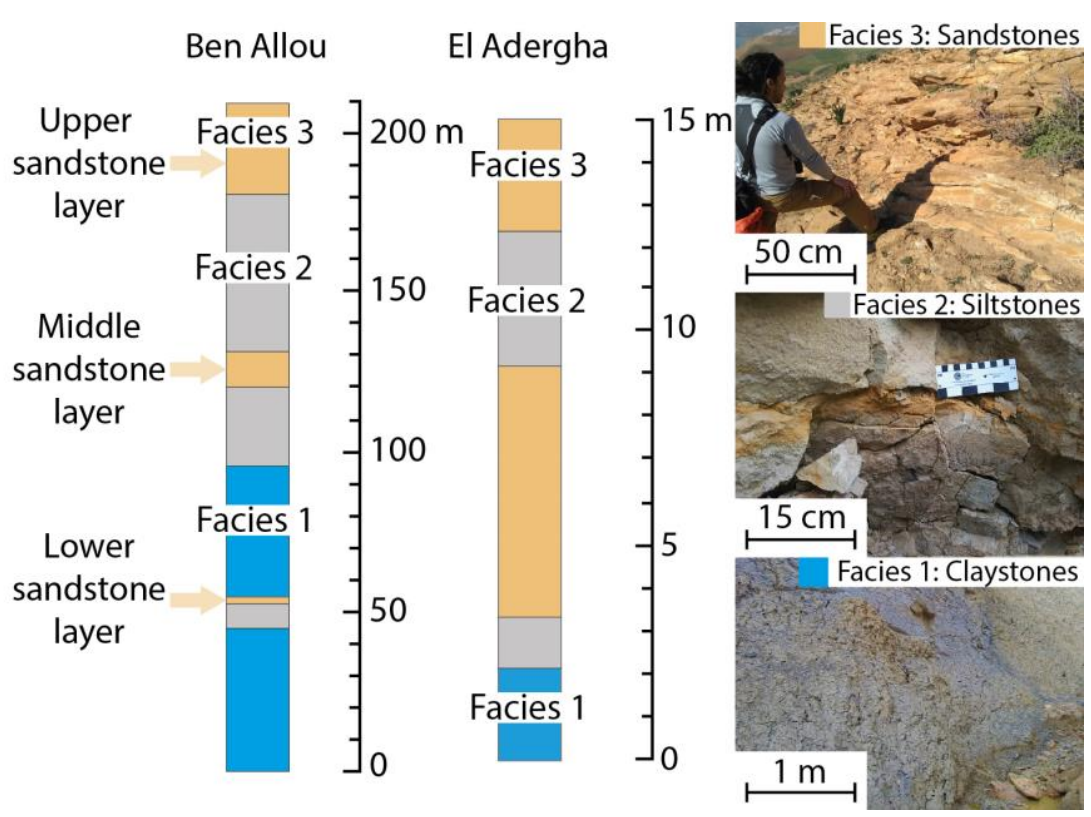

Figure 2. Left: stratigraphic logs of the exposures at Ben Allou and El Adergha. Exposed stratigraphic thickness at Ben Allou is 209 meters, thickness at El Adergha is 15 meters. All three facies are present at both locations. Right: Photographs showing the three facies. 

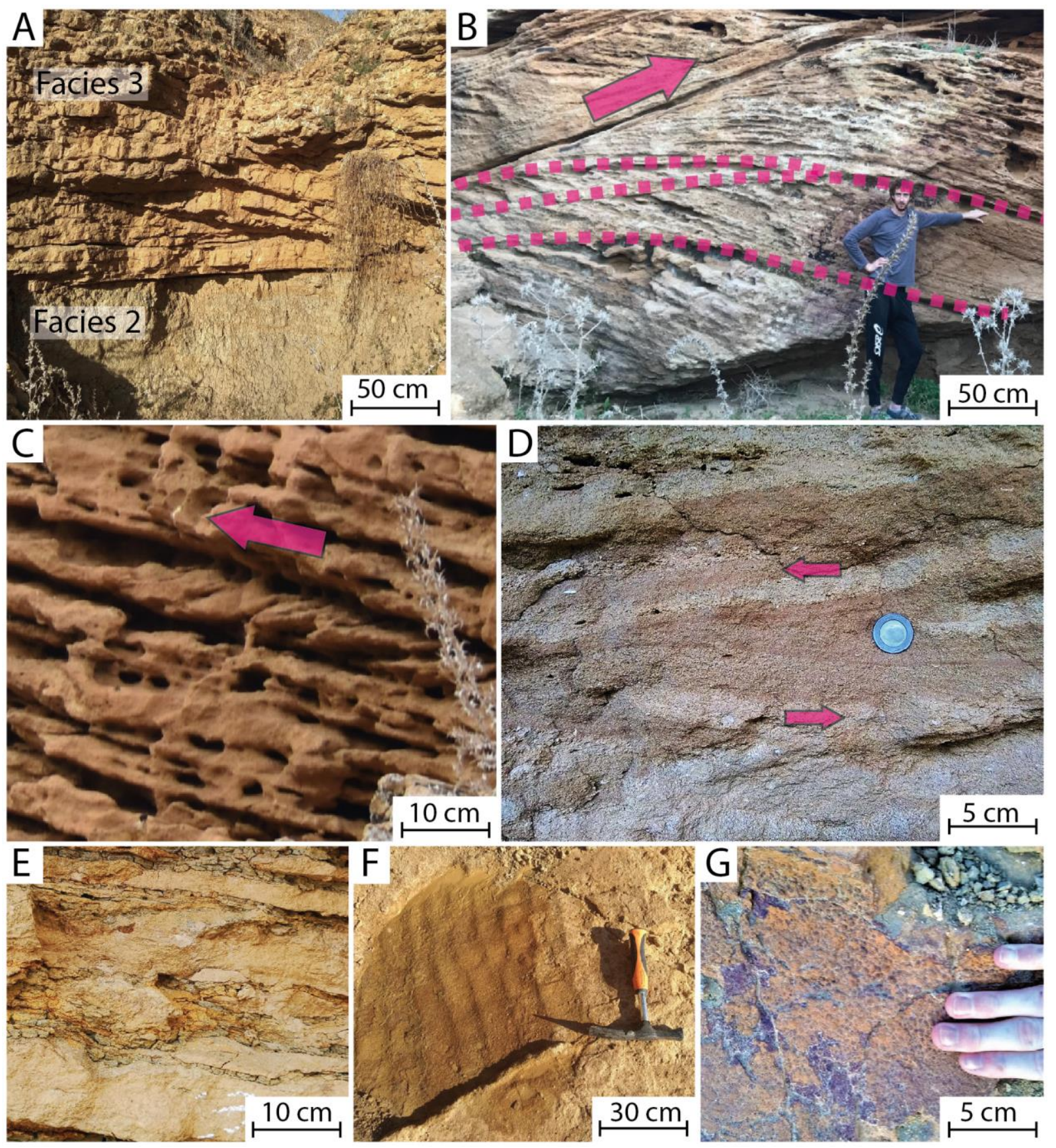

Figure 3. A: Erosional boundary at the bottom of the upper sandstone layer. Cross stratified sandstones are above the boundary and grey marls are below the boundary. B: Large cross strata in the sandstones containing reactivation surfaces (marked by dashed pink lines), pink arrow shows paleocurrent direction. C: Inclined heterolithic stratifications, pink arrow shows paleocurrent direction. D: Bidirectional cross strata. Pink arrows show paleocurrent directions. E: Flaser bedding. F: Symmetrical ripples with a prominent Ophiomorpha burrow. G: Siderite-rich paleosol with a pustular texture. 


\section{Paleontology}

The sandstones (facies 3) have a high variability in bioturbation intensity and contain abundant, Planolites and Psilonichnus ichnogenera near the top of the sandstone layers and abundant Thalassinoides, Macaronichnus and Scolicia ichnogenera along the bottom of the sandstone layers. Intervals of intense bioturbation are common. Overall, the sandstone layers exhibit a Glossifungites ichnofacies near the top and a Cruziania ichnofacies at the bottom (Pemberton and Frey, 1984). We note that existing studies on the trace fossils of these deposits like Miguez-Salas et al. (2021) appear to have missed the abundant Psilonichnus borings, which are the dominant inchnogenus near the tops of the sandstone layers. There are many complete barnacles and $1-3 \mathrm{~cm}$ sized scallop macrofossils as well as $5-10 \mathrm{~mm}$ sized bryozoa and echinoid fragments. Sediments are poorly sorted and immature, mostly consisting of coarse shell debris and some immature euhedral quartz grains. In the sandstones (facies 3), benthic foraminifera of genus Ammonia and Elphidium are the dominant species, accounting for around half of all foraminifera (Fig. 4). These genera are consistent with a nearshore environmental interpretation and a shallow depositional water depth (Murray, 2014). Other shallow water benthics such as Quinqueloculina and Amphigestina account for most other benthic genera in these sandstone deposits. Species associated with brackish water, notably Ammonia tepida are present (Debenay et al. 1998). $\pm 16 \%$ of foraminifera belong to planktonic genera, such as Globogerinoides or Neogloboquadrina. Foraminifera are outnumbered by numerous species of smooth-shelled ostracods. The foraminiferal assemblages in these sandstones are very similar to stromatolite-bearing assemblages from contemporaneous lagoonal deposits at the nearby outcrop locality of Driouate (Fig. 1; Beelen et al., 2020). The outcrop of Driouate lies $\pm 9 \mathrm{~km}$ south (interpreted paleo landward) from the location of Ben Allou (Beelen et al., 2020). Foraminifera collected from the sandstones at Ben Allou are in nearperfect preservation condition, indicating that they are not part of a reworked and redeposited assemblage (Fig. 5). Water depth-dependent ratios of planktonic (water column dwelling) and benthic (sea floor dwelling) species (P/B ratios; van der Zwaan et al., 1990) show that, while the sandstones have a dominance of benthics (facies $3, \mathrm{P} / \mathrm{B}=0.16$ ), there is a more than six fold increase in the fraction of planktonic individuals in the more distally deposited siltstones (facies $2, \mathrm{P} / \mathrm{B}=1.12$ ) and the claystones (facies $1, \mathrm{P} / \mathrm{B}=1.30$ ). The siltstones and claystones also have assemblages that are consistent with much deeper water settings (Figs. 4, 5), having far fewer Ammonia and Elphidium and ostracods $(<10 \%)$. These assemblages also have benthic genera associated with deeper environments like Cibicides and Pullenia.

In contrast to the sandstones (facies 3 ), the finer facies ( 1 and 2 ) have almost no sedimentary structures and instead have a mostly homogeneous texture (Fig. 2). In some cases however, the siltstones (facies 2) are intercalated with coarse-grained, planar and ripple laminated heterolithic beds. The claystones (facies 1) contain microscopic Chondrites trace fossils, have $\pm 1 \%$ organic matter, and contain large calcareous concretions (Beelen et al., 2020). 


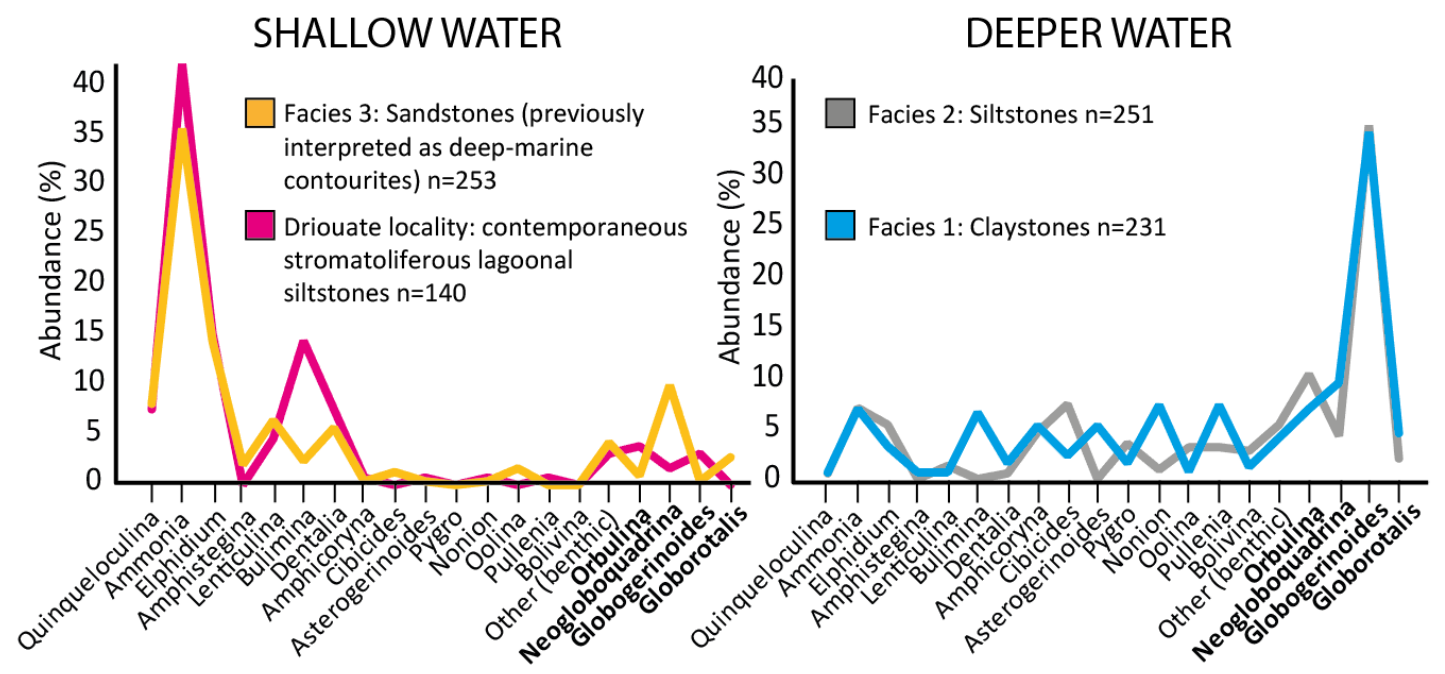

Figure 4. Foraminiferal assemblages. Left: shallow water assemblages in the lagoonal facies at Driouate (pink) as compared to similar contemporaneous assemblages in the Ben Allou and El Adergha sandstones (orange, facies 3). Right: foraminiferal assemblages consistent with deeper depositional water depths in the siltstones (grey, facies 2) and claystones (blue, facies 1). Foraminiferal genera are on the $X$-axis. Planktonic genera are in bold, showing much higher planktonic/benthic ratios in the finegrained facies ( 1 and 2) as compared to the coarser facies 3. Assemblages are from various intervals at the locations of Ben Allou and El Adergha.
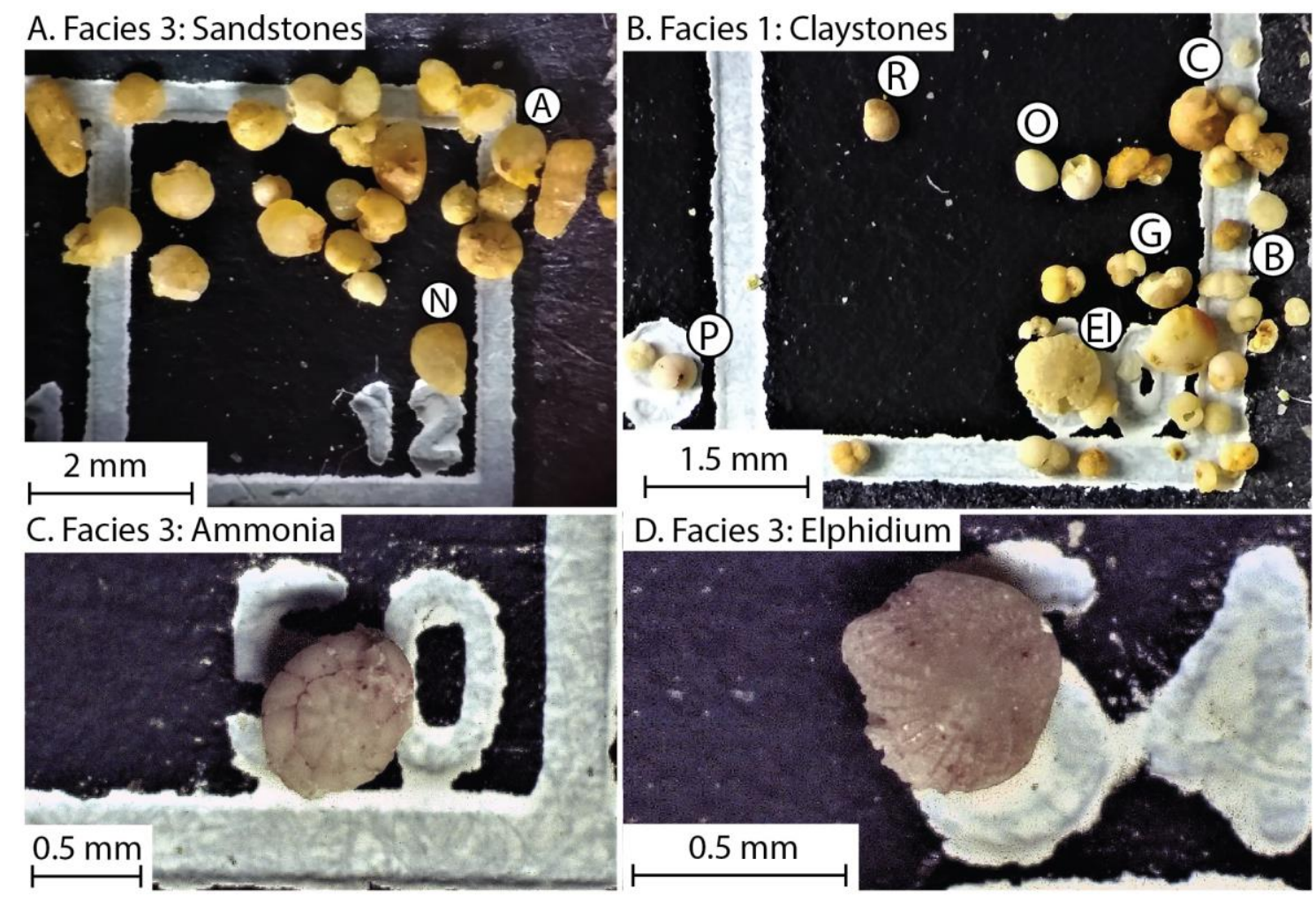

Figure 5. A: Sample of 25 foraminifera from facies 3: Sandstones. Sample was obtained from the middle sandstone layer at Ben Allou (Fig. 2). This sample shows dominantly benthic foraminifera, the 
most common genus is Ammonia. $A=$ Ammonia, $N=$ Nonion. $B$ : Sample of 35 foraminifera from

facies 1: Claystones. Sample was obtained from the claystones near the bottom of the Ben Allou succession. This sample shows dominantly planktonic foraminifera and deeper water benthics like Pullenia and Cibicides. $R=$ Rotalina, $O=$ Oolina, $P=$ Pullenia, $C=$ Cibicides, $E l=$ damaged and possibly reworked Elphidium, $G=$ Globogerinoides, which is the dominant genus in this facies. $B=$ Bulimina. C: Sample of Ammonia, the dominant genus in facies 3: Sandstones. Note that lack of damage indicates that this specimen was likely deposited in situ, and was not reworked. D: Sample of the second most common genus in facies 3: Sandstones: Elphidium.

\section{INTERPRETATIONS}

The sandstones (facies 3) have microfossil assemblages dominated by Ammonia and Elphidium genera (Fig. 4). Macrofossils in these rocks are mostly barnacle and echinoid fragments (Beelen et al., 2020). The presence of these fossils is consistent with a shallow marine, nearshore depositional environment for the sandstones. Furthermore, the assemblage of sedimentary structures in the sandstones such as: rhythmic bedding, reactivation surfaces, inclined heterolithic stratifications, bidirectional cross strata, flaser bedding and mud drapes, suggests that these rocks formed under the action of shallow marine tidal processes. The poorly sorted and immature textures of the Ben Allou and El Adergha sandstones, as well as the numerous channels shows that the sandstones were not formed by persistent, deep marine bottom current or geostrophic processes. Instead, these deposits formed in a much shallower tidedominated setting, where rapid currents frequently alternated with flow quiescence (Davis and Dalrymple, 2011; Beelen et al., 2020). Correspondingly, the alternating fine-to coarse-grained sedimentary fill of the channels are interpreted as tidal couplets reflecting episodes of waxing and waning tidal currents (Fig. 3C; Davis and Dalrymple, 2011). The ferruginous red hardgrounds in the sandstones (Fig. 3G) have likely been diagenetically altered and may have been in contact with welloxygenated meteoric pore waters, indicating proximity to the air (Wright, 1994). Proximity or intermittent contact with air is further supported by the firm, dewatered paleo-consistency of the sandy substrates as reflected by the numerous Psilonichnus borings and Glossifungites ichnofacies (Gingras et al., 2000), as well as the presence of tepee structures and mud cracks (Beelen et al., 2020). Although rare, the presence of some beds containing symmetrical ripples (Fig. 3C), suggest that some of the sandstones were also affected by waves. Aside from these minor occurrences, most evidence of wave action is likely obscured by the more powerful, amplified tidal processes that occurred in the paleo sea strait depositional setting (Beelen et al., 2020).

Microfossils, macrofossils and trace fossils in the fine-grained claystone and siltstone facies (1 and 2), demonstrate that these formed in an open marine environment under significantly deeper waters. The much finer-grained, grey siltstones (facies 2), lack sedimentary structures and are intercalated with heterolithic beds that are interpreted as turbidites. These observations suggest that these sediments were deposited in a more distal, sloped setting, where low-energy environments and sediment gravity flows 
dominated the depositional process regime (e.g. Rich, 1951). Thin sections of the turbidites show many crushed and severely damaged foraminifera and macrofossils that are consistent with assemblages from the overlying sandstones (facies 3). This faunal material in facies 2 was thus likely derived from the more proximal sandstone facies and then resedimented and incorporated in the more distal siltstones. The micro-fauna and trace fossil assemblages, lack of sedimentary structures, and presence of large calcareous concretions and organic matter, indicate that the claystones (facies 1) were deposited under quiet, deep and dysoxic, possibly shelfal conditions (Martin, 2004; Yoshida et al., 2018).

The three facies documented at Ben Allou are also present at the much smaller exposure of El Adergha where they are similar in terms of sedimentary structures, as well as in microfossil, macrofossil and trace fossil assemblages and sedimentary structures. Our facies depositional environment interpretations are therefore the same for both locations. Based on these process and water depth interpretations, each cycle in the successions at Ben Allou and El Adergha thus has a shallowing upward facies trend.

\section{DISCUSSION}

\section{Late Tortonian global eustatic changes}

The relatively rapid stratigraphic alternations between the shallow water sandstones (facies 3) and deeper water siltstone and claystone facies (1 and 2) suggests that the Rifian Corridor was subject to large scale changes in paleo water depth. Based on this, we interpret the shallowing upwards stratigraphic cycles exposed at Ben Allou and El Adergha, as depositional sequences that each represent a relative rise and fall in sea level (Sarg, 1988; Van Wagoner et al., 1988; Fig. 6). Given this interpretation, the laterally extensive surfaces of erosion at the lower boundaries of the sandstone layers can be interpreted as regressive surfaces of marine erosion that formed during a developing lowstand in sea level (Figs. 3A; Van Wagoner et al., 1988). The succession at Ben Allou shows a thickening of the shallower facies component of each successive sequence, which possibly reflects a progradational stacking of sequences throughout the development of periodically changing sea level conditions (Fig, 6). Based on this evidence, we argue that the observed shifts in microfossil assemblages and facies in the exposed Rifian Corridor fill at Ben Allou and El Adergha are linked to sea level fluctuations (Fig. 7). This interpretation is supported by the fact that large scale global fluctuations in late Miocene sea level have been documented in existing literature. Notably, contemporaneous sediments that formed in the Betic Corridor in Spain (Garcia-Garcia et al., 2009), as well as ocean drill cores from offshore Morocco (Cita and Ryan, 1979; Westerhold et al., 2005) provide evidence for large, periodic shifts in global temperature and sea level in these areas, that were prevalent during the late Miocene and late Tortonian. Furthermore, biostratigraphic age markers from Capella et al., (2017) indicate that the three, roughly equally thick depositional sequences at Ben Allou were deposited between 7.80 and $7.50 \mathrm{Ma}$, reflecting $\pm 100 \mathrm{kyr}$ per cycle (Fig. 6). This value corresponds in periodicity to existing interpretations 
of late Tortonian sea level changes, which were likely driven by $100 \mathrm{kyr}$ orbital eccentricity cycles (Cita and Ryan, 1979). Furthermore, the thickness of a depositional sequence can approximate the minimum variability in water depth across coeval sea level fluctuations (Plint, 2009; Beelen et al., 2019). Based on the measured thicknesses of the sequences at Ben Allou, sea level changes during the late Tortonian in this area were at least $70 \mathrm{~m}$, likely between $70-80 \mathrm{~m}$ in amplitude. Our data on the period and amplitude of sea level fluctuations at Ben Allou are thus in general agreement with previous studies on late Tortonian eustatic changes, which were based on measured variations in oxygen isotopes and reported $\pm 80 \mathrm{~m}$ sea level fluctuations across $100 \mathrm{kyr}$ periods (Cita and Ryan, 1979; Westerhold et al., 2005). These older studies conclude that periodic changes in sea level during the late Miocene were glacioeustatic in nature, and were forced by $100 \mathrm{kyr}$ orbital eccentricity cycles. Evidence presented in this study thus corroborates existing notions that late Miocene climate had an orbitally paced regime of glacial-interglacial cycles, similar in intensity and periodicity to Pleistocene glacial-interglacial climate changes (Cita and Ryan, 1979). These fluctuations are far more intense than during the generally warmer and more stable Pliocene climate that existed in between the Pleistocene and the late Miocene (Miller et al., 2005). The data and interpretations presented here also support existing opinions that, in addition to compressional tectonics, the confinement of the Rifian Corridor also occurred periodically due to rapid glacioeustatic variations, immediately prior to the Messinian salinity crisis (e.g. Hilgen et al., 2007). These periodic confinements may not have played a significant role in the onset of the Mediterranean desiccation, but likely affected MOW, Atlantic Deep water formation and possibly regional or global climate. Additionally, our findings lead us to propose that the constriction and disappearance of the Rifian Corridor was hastened by rapid infill of the Rif Foreland's accommodation from high sediment supply. This high sediment supply was facilitated by abundant carbonate sediment production from active, shallow marine carbonate factories, located at the fringes of the MediterraneanAtlantic gateway corridors, such as those that are now partially exposed at Ben Allou and El Adergha. 


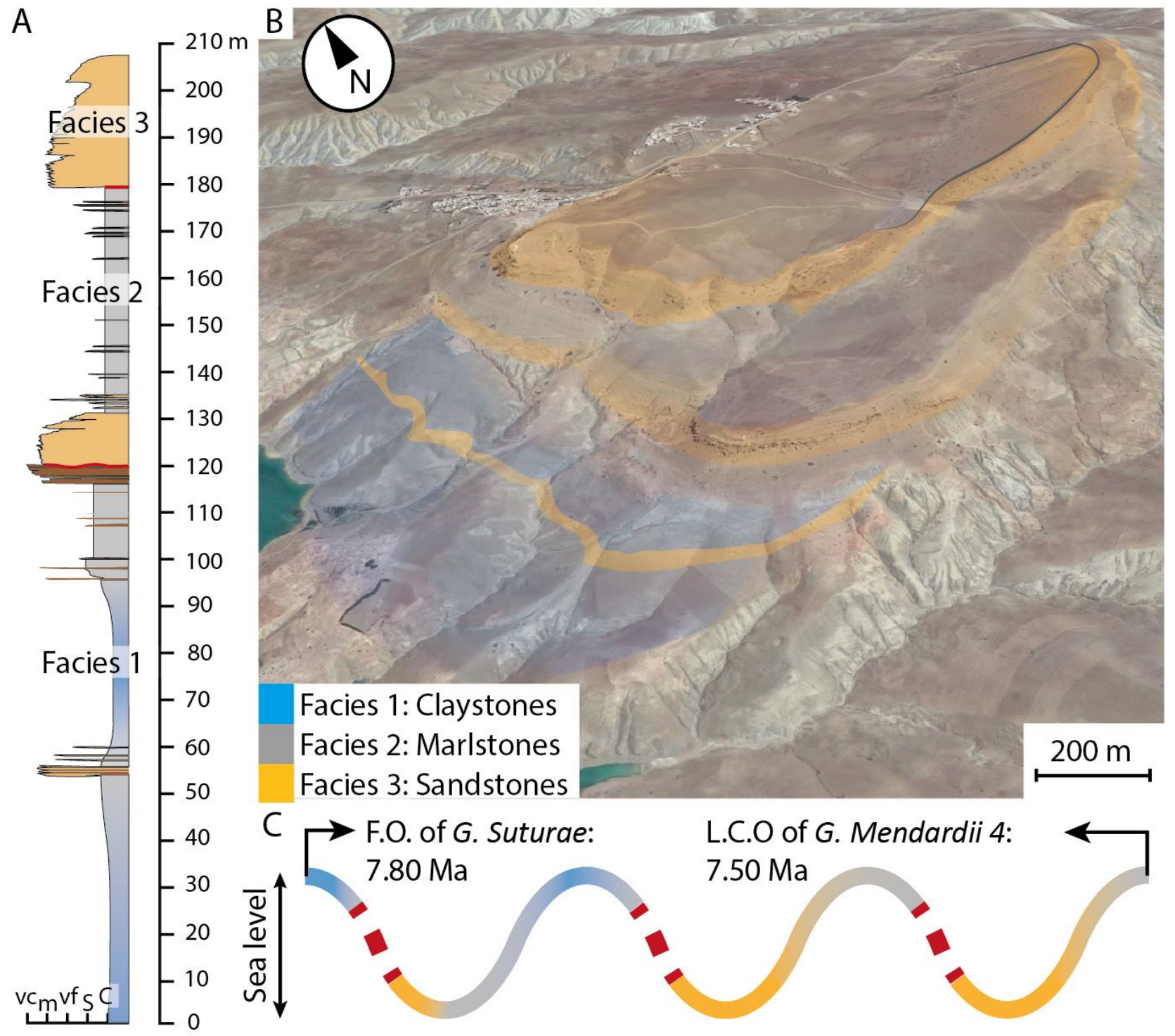

Figure 6. Overview of the outcrops at Ben Allou (sometimes called Sidi Chahed). See figure 1 for location. A: Sedimentary log of the 209 m thick succession at Ben Allou, showing three stratigraphic cycles that each contain facies 1, 2 and 3. B: Satellite image showing cliff forming sandstones, image is overlain by a facies interpretation of the Ben Allou outcrops, showing claystones (facies 1) in blue, siltstones (facies 2) in grey and sandstone layers (facies 3) in orange. C: paleo sea level interpretation for the various facies, showing high relative sea level corresponds to the deposition of siltstones and claystones (facies 1 and 2) and low relative sea level corresponds to the deposition of sandstones (facies 3). Red hashed line denotes erosional hiatus that coincides with the developing lowstand. F.O. = First Occurrence. L.C.O. = Last Common Occurrence. Biostratigraphic age constraints from Capella et al., 2017 show that the three cycles within the exposed interval were deposited between 7.80 and $d 7.50$ Ma, suggesting sea level fluctuations here occurred roughly every 100.000 years. 


\section{Shallow or deep? A reinterpretation of the depositional processes}

Many existing models for the depositional processes in the Rifian Corridor rely on the interpretation that the sandstones at Ben Allou and El Adergha were formed in deep water, under the action of deep marine geostrophic bottom currents. Firstly, Capella et al. (2019) argue that the contact between the siltstone facies (2) and the sandstone facies (3) at Ben Allou signifies a sudden increase in bottom current intensity and MOW during the late Tortonian. They then discuss whether this increase in bottom currents corresponds to shifts in ocean current intensity and changes in Miocene atmospheric conditions and paleoclimate. Secondly, Miguez-Salas et al. (2020a) argue that ichnofossil assemblages in the sediments at Ben Allou reflect shifts in nutrient supply and associated bottom current activity. Thirdly, de Weger et al. (2020) claim that the sandstones at Ben Allou have bottom current channels that display intermittent overflow of MOW currents in this area. They then discuss that this intermittent development of ocean currents reflects changes in tectonics, regional climate and global ocean circulation. Fifthly, Miguez-Salas et al. (2011) base their deep marine contourite ichnofacies model on these sediments. Finally, Stow and Similie (2020) base their coarse-grained contourite facies model largely on observations made at Ben Allou and El Adergha. New evidence presented here, which shows that the sandstones at Ben Allou and El Adergha were actually formed in shallow water by tidal currents, indicates that some conclusions from the aforementioned studies require revision.

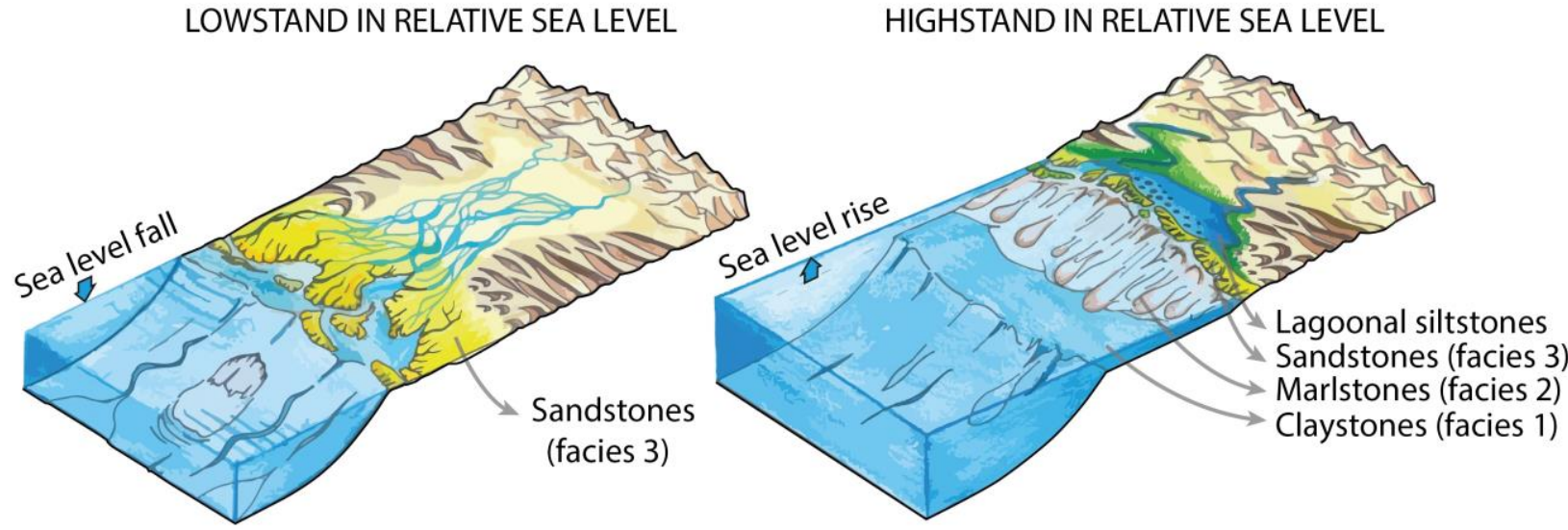

Figure 7. Paleoenvironmental interpretations. Schematic image illustrating facies shifts from shallow water sandstones (facies 3) during a relative sea level highstand (left) to deeper siltstones and claystones (facies 1 and 2) during a relative sea level lowstand (right).

\section{CONCLUSIONS}

This study focusses on Miocene-aged sedimentary successions that formed in the Rifian Corridor and are now exposed in the Fez-Meknes region of northern Morocco, at the locations of Ben Allou and El Adergha. Micro fauna, macro fauna and trace fossil assemblages, immature sediments, symmetrical ripples, rhythmic bedding and flaser bedding are present in sandstone layers that make up part of this 
exposed sedimentary fill. These observations independently show that the sandstones formed in a tidedominated, nearshore, shallow water environment. Considering this evidence, it is argued that these sandstones do not represent deep water contourite deposits that formed under the action of deep marine geostrophic bottom currents or MOW, as was claimed by previous studies. Some conclusions from previous studies that infer variations in bottom current activity, paleoclimate and paleo environment from these sandstones thus require reinterpretation. Additional sedimentary and paleontological evidence is provided to show that the fine grained siltstone and claystone facies ( 1 and 2$)$ that interbed the sandstones at Ben Allou and El Adergha formed in much deeper waters. This suggests that large \pm 70 - $80 \mathrm{~m}$ paleo-water depth fluctuations occurred in the Rifian Corridor during the late Tortonian. These fluctuations can be linked to late Miocene glacioeustatic variations, which were likely forced by $100 \mathrm{kyr}$ orbital eccentricity cycles and were overall similar in period and intensity as Pleistocene glaciations.

\section{REFERENCES}

Beelen, D., Jackson, C. A. L. Patruno, S. Hodgson, D. M. Trabucho Alexandre, J. P. (2018) Rising not falling? Differential compaction of shelf-edge trajectories and clinothem geo-metries. Geology. 47(11), 1011-1014.

Beelen, D. Wood, L.J. Zaghloul, M.N. Haissen, F. Arts, M. Ouahbi, I. Cardona, S. Redoaune, M. (2020) Tide-dominated deltas responding to high-frequency sea level changes, Pre-Messinian Rifian Corridor, Morocco. Journal of Sedimentary Research, 90, 1-25.

Capella, W. Hernández-Molina, F.J. Flecker, R. Hilgen, F.J. Hssain, M. Kouwenhoven, T.J. Tulbure, M.A. (2017) Sandy contourite drift in the late Miocene Rifian Corridor (Morocco): Reconstruction of depositional environments in a foreland-basin seaway. Sedimentary Geology, 355, $31-57$.

Capella, W. Flecker, R. Hernández-Molina, F.J. Simon, D. Meijer, P.P.T. Rogerson, M Krijgsman, W. (2019) Mediterranean isolation preconditioning the Earth System for late Miocene climate cooling. Scientific reports, $\mathbf{9 ( 1 )}, 1-8$.

Cita, M.B. and Ryan, W.B.F. (1979) Late Neogene environmental evolution, Initial Reports, Deep Sea Drilling Project (Eds. von Rad, U. et al.), 47, 447-459.

Davis Jr, R.A. and Dalrymple, R.W. (2011) Principles of tidal sedimentology. Springer Science and Business Media.

Debenay, J.P. Bénéteau, E. Zhang, J. Stouff, V. Geslin, E. Redois, F. Fernandez-Gonzales, morphofunctional arguments for their distinction: Marine Micropaleontology, 34, 235-244.

Dunham, R.J. (1962) Classification of carbonate rocks according to depositional textures. In: Classification of Carbonate Rocks-A Symposium, American Association of Petroleum Geologists, 1, 108-121.

Garcia-Garcia, F. Soria, J.M. Viseras, C. Fernandez, J. (2009) High-frequency rhythmicity in a mixed siliciclastic-carbonate shelf (Late Miocene, Guadix Basin, Spain): a model of interplay between climatic oscillations, subsidence, and sediment dispersal: Journal of Sedimentary Research, 79(5), 302315 . 
Gingras, M.K. Pemberton, S.G. Saunders, T. (2000) Firmness profiles associated with tidal-creek deposits: the temporal significance of Glossifungites assemblages. Journal of Sedimentary Research, 70(5), 1017-1025.

Grabau, A.W. (1904) On the classification of sedimentary rocks. American Geologist, 33, 228-247.

Hilgen, F., Kuiper, K., Krijgsman, W., Snel, E., van der Laan, E. (2007) Astronomical tuning as the basis for high resolution chronostratigraphy: the intricate history of the Messinian Salinity Crisis. Stratigraphy, 4(2-3), 231-238.

Hüneke, H. and Stow, D.A. (2008) Identification of ancient contourites: problems and palaeoceanographic significance. Developments in Sedimentology, 60, 323-344.

Ivanovic, R.F. Flecker, R. Gutjahr, M. and Valdes, P.J. (2013) First Nd isotope record of Mediterranean-Atlantic water exchange through the Moroccan Rifian Corridor during the Messinian salinity crisis. Earth and Planetary Science Letters, 368, 163-174.

Knutz, P.P.C. (2008) Palaeoceanographic significance of contourite drifts. Developments in Sedimentology, 60, 511-535.

Llave, E. Schönfeld, J. Hernández-Molina, F.J. Mulder, T. Somoza, L. Del Río, D. SánchezAlmazo, (2006) High-resolution stratigraphy of the Mediterranean outflow contourite system in the Gulf of Cadiz during the late Pleistocene: the impact of Heinrich events. Marine Geology, 227(3-4), 241-262.

Plint, A.G., Tyagi, A., Hay, M.J., Varban, B.L., Zhang, H., \& Roca, X. (2009) Clinoforms, paleobathymetry, and mud dispersal across the Western Canada Cretaceous foreland basin: evidence from the Cenomanian Dunvegan Formation and contiguous strata. Journal of Sedimentary Research, 79(3), 144-161.

Rebesco, M. Hernández-Molina, F.J. Van Rooij, D. Wåhlin, A. (2014) Contourites and associated sediments controlled by deep-water circulation processes: state-of-the-art and future considerations. Marine Geology, 352, 111-154.

Martin, K.D. (2004) A re-evaluation of the relationship between trace fossils and dysoxia. Geological Society, London, Special Publications, 228(1), 141-156.

Miguez-Salas, O. Rodríguez-Tovar, F.J. De Weger, W. (2020a) Macaronichnus and contourite depositional settings: Bottom currents and nutrients as coupling factors. Palaeogeography, Palaeoclimatology, Palaeoecology, 545, 109639.

Miguez-Salas, O. and Rodríguez-Tovar, F.J. (2020b) Trace fossil analysis of sandy clastic contouritic deposits in the late Miocene Rifian Corridor (Morocco): Ichnotaxonomical and palaeoenvironmental insights. Journal of African Earth Sciences, 104054.

Miguez-Salas, O, Rodríguez-Tovar, F. de Weger, W. (2021) Exploring Ichnofacies Distribution in Ancient Seaways: The Late Miocene Rifian Corridor as a Natural Laboratory. Scientific Reports, 11, 4198.

Miller, K. G., Kominz, M. A., Browning, J. V., Wright, J. D., Mountain, G. S., Katz, M. E. Sugarman, P.J. Cramer, B.S. Blick, N.C., Pekar, S. F. (2005). The Phanerozoic record of global sealevel change. science, $\mathbf{3 1 0}(\mathbf{5 7 5 2}), 1293-1298$.

Murray, J. W. (2014) Ecology and palaeoecology of benthic foraminifera. Routledge. 
Pemberton, S.G., and Frey, R.W. (1984) The Glossifungites ichnofacies: modern examples from the Georgia coast, USA. In: Biogenic structures: Their use in interpreting depositional environments, (ed. Allen Curran), SEPM, Special publications. 35, 237-261.

Shanmugam, G. Spalding, T.D. Rofheart, D.H. (1993) Process sedimentology and reservoir quality of deep-marine bottom-current reworked sands (sandy contourites): an example from the Gulf of Mexico. AAPG Bulletin, 77(7), 1241-1259.

Stow, D.A. Faugères, J.C. Viana, A. Gonthier, E. (1998) Fossil contourites: a critical review. Sedimentary Geology, 115(1-4), 3-31.

Stow, D. and Smillie, Z. (2020) Distinguishing between Deep-Water Sediment Facies: Turbidites, Contourites and Hemipelagites. Geosciences, 10(2), 68.

Sarg, J.F. (1988) Carbonate Sequence Stratigraphy. In: Sea-Level Changes: An Integrated Approach (Eds. C.K. Wilgus, B.S. Hastings, C.A. Ross, H. Posamentier, J. Van Wagoner, J.C. Kendall C.G.St.C). SEPM, Special Publication, 42, 155-183.

Rich, J.L. (1951) Three critical environments of deposition, and criteria for recognition of rocks deposited in each of them. Geological Society of America Bulletin, 62(1), 1-20.

Van der Zwaan, G.J. Jorissen, F.J. De Stigter, H.C. (1990) The depth dependency of planktonic/benthic foraminiferal ratios: constraints and applications. Marine Geology, 95(1), 1-16.

Van Wagoner, J.C. Posamentier, H.W. Mitchum, R.M.J. Vail, P.P.R. Sarg, J.F. Loutit, T.S. Hardenbol, J. (1988) An overview of the fundamentals of sequence stratigraphy and key definitions. In: Sea-Level Changes: An Integrated Approach (Eds. C.K. Wilgus, B.S. Hastings, C.A. Ross, H. Posamentier, J. Van Wagoner, J.C. Kendall C.G.St.C ). SEPM, Special Publication, 42, 155-183.

Viana, A.R. Almeida, W. Nunes, M.C.V. Bulhões, E.M. (2007) The economic importance of contourites. Geological Society, London, Special Publications, 276(1), 1-23.

Viana, A.R. and Rebesco, M. (2007) Economic and palaeoceanographic significance of contourite deposits. Geological Society of London.

de Weger, W. Hernández-Molina, F.J. Flecker, R. Sierro, F.J. Chiarella, D. Krijgsman, W. Manar, M.A. (2020) Late Miocene contourite channel system reveals intermittent overflow behavior. Geology, 48(12), 1194-1199.

Westerhold, T. Bickert, T. Röhl, U. (2005) Middle to late Miocene oxygen isotope stratigraphy of ODP site 1085 (SE Atlantic): new constrains on Miocene climate variability and sea-level fluctuations. Palaeogeography, Palaeoclimatology, Palaeoecology, 217(3-4), 205-222.

Wright, V.P. (1994) Paleosols in shallow marine carbonate sequences: Earth-Science Reviews, 35(4), p. 367-395.

Yoshida, H. Yamamoto, K. Minami, M. Katsuta, N. Sin-ichi, S. Metcalfe, R. (2018) Generalized conditions of spherical carbonate concretion formation around decaying organic matter in early diagenesis. Scientific reports, 8(1), 1-10.

Zizi, M. (1996) Triassic-Jurassic extensional systems and their Neogene reactivation in northern Morocco (the Rides prérifaines and Guercif basin) Dissertation Rice University. 


\section{ACKNOWLEDGEMENTS}

We thank Professor Faouziya Haissen for her help and initiative in organizing our expedition. We also thank Mouttaqi Abdellah and Ismail Ouahbi from OHNYM for their extraordinary courtesy and logistic support. Finally, we express our thanks to Meryem Redouane and Sebastian Cardona for their assistance in the field.

The data that support the findings of this study are openly available. Please contact: dbeelen@ mines.edu 